\title{
Small Investor Demand and Allocation in Commercial Bank Managed IPOs
}

\author{
by \\ Manju Puri and Jörg Rocholl ${ }^{\ddagger}$
}

March 2006

\begin{abstract}
There is a burgeoning literature on IPO allocations to institutions with retail clientele typically being treated as a monolithic entity. However, there is potential for differential treatment of different groups of retail investors because of the underlying relationship with the underwriter. We use a unique proprietary dataset from Germany to analyze how commercial banks treat different groups of retail investors in their underwriting of new equity issues. Do banks take advantage of retail investors to dump "lemons" or do their retail investors benefit from getting higher allocation of underpriced issues? We provide evidence that lead underwriters' retail customers demand more of the highly underpriced issues and end up with a higher allocation of underpriced issues. We additionally provide evidence on the underlying incentives of the bank to treat their retail clientele well by examining cross-selling potential from other services of the bank. In particular, we document an increase in both new brokerage accounts and retail consumer loans which are related to increased IPO underwriting, especially underwriting of underpriced IPOs by the commercial bank. Our results support the notion that the underlying relationship with the retail clientele and the potential to offer other services can not only result in differential or favored retail treatment but can lead to incentives for the bank to underprice IPOs to attract new retail customers. This suggests a number of new research questions relevant in many regimes including the current US regulatory setting where both commercial banks and investment banks underwrite.

† Duke University and NBER. Email: mpuri@duke.edu. Tel: (919) 660-7657;

* University of North Carolina. Email: Jorg_Rocholl@unc.edu. Tel: (919) 962-8466.

We thank seminar participants and discussants at the Federal Reserve Bank Chicago, Ohio University, University of North Carolina, 10th Symposium on Finance, Banking, and Insurance in Karlsruhe, and the Symposium on Corporate Finance at the Hong Kong University of Science and Technology.
\end{abstract}




\section{Introduction}

In a review of recent IPO literature Ritter and Welch (2002) state "...research into share allocation issues is the most promising area of research in IPOs at the moment." A large amount of recent research has focused on the role of institutions in the book building process and its resultant implications for the pricing process and allocations. Hanley and Wilhelm (1995); Aggrawal et. al. (2002) both examine the relationship between institutional allocation and underpricing and find that institutions seem to get favorable allocations. Cornelli and Godreich $(2001,2003)$ find that institutions providing pricing information are more likely to get higher allocations. These results are broadly consistent with book building models as in Benveniste and Spindt (1989).

In stark contrast to the burgeoning literature studying institutional allocations, there has been virtually no research that examines different classes of retail clientele. The assumption in the literature has implicitly been that retail clientele are a monolithic entity. However, different groups of retail clientele can receive different treatment based on their relationship with the underwriter. Do underwriter relationships with retail clients matter and how far does it influence the IPO process? There can be incentives to favor certain clientele through preferable allocation. A less obvious way to influence the ultimate profits of clientele is by influencing the demand for IPOs, in particular demand for underpriced IPOs. Our paper contributes by bringing some of the first empirical evidence to bear on this question.

A key arena in which the distinction between different groups of retail clientele is quite stark and also controversial, is when the retail clientele also has a deposit account relationship with the underwriter. One of the issues behind regulation surrounding the separation of commercial and investment banking in the US (mandated by the Glass-Steagall Act of 1934 and repealed by Gramm-Leach-Bliley Act of 1999) has been when commercial banks underwrite how might this influence how banks treat their depositors? On the one hand banks might take advantage of their own depositors to dump "bad issues." Alternatively, banks might want to inform their customers of good issues, and perhaps also allocate more of such issues where they are the lead manager. Empirically this is a difficult question to address because demand and allocation data for IPOs as well as the identity of the investors are generally not available. The only way to empirically 
examine such a question would be to obtain proprietary data on demand and allocation to different categories of retail clientele. In addition, we need a sample of underwriters who are commercial banks whose account holders would potentially form a significant part of the retail demand of the IPOs being underwritten by the bank. Further we would need additional data on the banks themselves to test the incentives and behavior of banks to treat their retail clientele in particular ways.

Our approach is therefore to exploit the German setting, which is a country where commercial banks have a strong presence in equity underwriting. We request for proprietary information from the top five underwriters (who are commercial banks) both on demand and allocation for IPOs for different kinds of retail clientele. Using this data we are able to distinguish between lead retail clientele and other retail customers. We find interesting differentials between these classes of retail clientele. Our evidence suggests that the demand of the lead banks' own retail clientele is much higher for underpriced issues than for overpriced issues. Interestingly, this pattern is not observed in the demand data for other retail customers who are not the banks' customers. There is an upward trending demand pattern for the lead banks' own retail customers - they demand more for highly underpriced issues and less of the overpriced issues. In contrast, we find that the demand by banks' other retail customers is downward trending - they demand more of the overpriced issues and less of the underpriced issues. We further find some evidence that allocation shares for lead and non lead bank customers differ, with lead bank retail clientele likely to get a higher allocation of underpriced issues, but most of this allocation differential comes from the differential demand pattern

The natural question that follows from this is why do banks not take advantage of depositors to dump their bad issues? One powerful incentive for banks to treat their retail depositors fairly is that it allows banks to use their underwriting of IPOs as a way to attract other retail business to the bank. ${ }^{1}$ If this is indeed the case we should see that banks which actively engage in underwriting are able to use their underwriting business to boost their other businesses. To test

\footnotetext{
${ }^{1}$ Our argument here, while it applies to retail customers rather than large customers, has some parallels with the reasoning by Fulghieri and Spiegel (1993) that banks allocate underpriced IPOs to large customers to promote sales in other business fields. On large customer interaction with investment banks, see also papers by Reuter (2006); Nimalendran, Ritter and Zhang (2006) which examine the relationship between commissions and IPO allocations.
} 
this we collect data from the Deutsche Bundesbank in Frankfurt. The Bundesbank has recently shown a greater willingness to open its doors to researchers. We are able to obtain information from the Bundesbank on brokerage accounts, consumer loans, and corporate loans for all major banks in Germany. Germany is a natural testing ground to address this question since Germany is not only the largest Continental European market for equity issues in the sample period but traditionally also German banks have been universal banks. Further, we have a natural control sample of banks that do not engage much in underwriting versus the banks who are big players in underwriting.

We find that increased IPO activity, in particular, more underwriting of underpriced IPOs is associated with increased brokerage accounts. Interestingly, the brokerage accounts tend to be sticky and persist well after the IPO underwriting window shuts down leading to continued profits for the bank from the fixed fees on the brokerage accounts. We also find additional evidence consistent with cross selling in other arenas such as increased retail consumer loans which are also associated with an increase in underwriting of IPOs. We ask whether these results can be explained by alternative stories such as aggressive loan rates or deposit rates, lower brokerage fees, the general growth of the bank, or simply increased stock market participation. We obtain data that allow us to control for these factors and find our results are robust to the inclusion of these factors and also to the use of instruments. Our results are supportive of the notion that cross selling is an important by product of IPO underwriting for commercial banks.

This research is related to a number of strands of literature. There is a large theoretical and empirical literature on IPOs which looks at the distinction between institutional and retail clientele with the notion that institutional clientele are either better informed and/or favored. However relatively little attention has been given to the importance and distinction between different kinds of retail clientele. With the growing importance of commercial banks in IPO underwriting this is an issue that assumes importance. Our research provides some of the first evidence on this dimension and suggests that there are valid reasons for commercial banks to take good care of their own retail account clientele. This is an interesting result because it suggests a number of new research dimensions. E.g., if cross-selling is important then this will 
naturally affect how banks treat their retail customers today and could also potentially affect the incentives for banks to underprice IPOs. This suggests impetus for theoretical research since these incentives can influence banks' behavior and how they deal with corporate firms in ways that are not obvious. This research also complements the literature that investigates the importance of cross-selling for corporate clientele for commercial banks (see e.g., Bharath et al $2005)$ by examining cross-selling from the retail perspective. ${ }^{2}$ In addition, this paper also has implications both for policy making and for the debate on the expansion and appropriate scope of bank activities.

\section{Data}

In order to test whether different groups of retail clientele are treated differentially, we need data both on the demand and allocation of IPOs for the lead bank's retail clientele vis-à-vis other retail clientele. In addition to examine underwriting banks' incentives in dealing with their retail clientele we also need information about the underwriting banks as well as a reasonable control group of banks who do not underwrite. To meet these dual objectives we obtain proprietary data from two very different sources. In both cases we also augment the data with publicly available data. The data sources are described below.

\subsection{The IPO data}

First, we would like to obtain all IPO demand and allocation data from all banks in Germany. However, given this is proprietary information that banks do not have to disclose this is clearly a very difficult task. Our first task is therefore to identify the most relevant underwriters to test our hypotheses at hand. The most important underwriters for our purpose are the banks with substantial retail depositors, the universal banks. These are the banks we would ideally like to get data from. Next, we want to control for reputation effects by obtaining data from banks with a comparable, high reputation. To get some ideas of numbers, the most active underwriter in this time period has a total of 44 IPOs. In the sample period, there are many new entrants into the

\footnotetext{
${ }^{2}$ Note that this is quite distinct from the literature that examines the relationship specific assets that lead to repeat underwriting (see e.g., James, 1992 or Drucker and Puri, 2005).
} 
German IPO business, many of which disappear even before the end of the sample period. This excludes banks that only have a minor market share and are not widely known before the sample period.

Given these criteria, we request demand and allocation data from the top five underwriters in the sample period between 1997 and 2004, which are universal banks and responsible for 156 IPOs. We receive these data for 84 IPOs, but we have to drop 12 IPOs because we lack crucial data, in particular subscription levels, leaving us with 72 IPOs which are about half of all IPOs underwritten by these banks in this time period. We have underwritings for each bank, ranging from a few to almost all underwritings by sample banks in this period. Banks provide us with the demand and allocation data for their own retail customers as well as demand and allocation data for retail customers of other banks. For all 72 issues we have information on the number of shares for which retail investors submit demand as well as the number of shares that is ultimately allocated to them. In addition for 44 of these IPOs we have aggregate retail demand and allocation split by the lead underwriter's retail clients and other retail clients. These data are supplemented by publicly available information from the issuing prospectuses and data sources as SDC and Factiva. This enables us obtain the overall subscription level for these issues.

\subsection{The Bundesbank Bank level data}

The second data set we collect consists of various confidential bank-specific statistics, which are provided by Deutsche Bundesbank, augmented with publicly available information from other sources. The Deutsche Bundesbank has recently allowed researchers to access its data. However, three restrictions apply. First, the data is in German, hence usage of it requires the requisite translation into English. Second, there is no centralized source of data; the data is spread across the Bundesbank so researchers need to do a careful search to find the relevant source of data. Third, the data cannot be taken out of the Bundesbank, so all data work and analysis has to be done on the premises of the Bundesbank in Frankfurt itself.

In order to decide which banks to request data from the Bundesbank, we first collect data from three sources of publicly available information. First, data on the number and percentage of 
shareholders in Germany in a given year are taken from the DAI-Factbook 2004. Second, the names of the underwriters for each German IPO are available from Deutsche Börse AG. These underwriters are ranked based on the number of IPOs that they brought to the market between 1992 and 2003. Third, the largest non-underwriting banks are identified from the 2002 ranking of the 100 largest German banks by the Association of German Banks (Bundesverband deutscher Banken). A list of the 32 largest underwriting and non-underwriting banks is created from these two data sources. This list forms the basis for our request for bank-specific data from the Bundesbank.

The Bundesbank allows researchers to work with figures for individual banks, but does not reveal the names of these banks. For this reason, the list of requested underwriting and nonunderwriting banks is merged with the bank-specific Bundesbank statistics by the Bundesbank. Individual banks are not identifiable from the merged dataset. Four of the banks are missing, as they merged during the sample period and data for some of the merging entities are not available. Four other banks substantially changed their reporting during the sample period and are dropped for this reason. The final nine missing banks are not considered as they had either no or less than 1,000 brokerage accounts. Consistent data are available for 15 of the 32 requested banks. For these 15 banks we have a wide variety of data available culled from different sources in the Bundesbank as described below.

The data set we use covers the time period between 1992 and 2003. The Bundesbank dataset is created from four sources. Balance sheet and income statement data on individual banks are from the monthly balance sheet statistics ("Monatliche Bilanzstatistik"). Data on the number and value of brokerage accounts come from the yearly brokerage account statistics ("Depotstatistik"). Information on bank loans to retail customers is provided by the borrower statistics ("Kreditnehmerstatistik"). Each German bank has to report these three statistics to the Bundesbank. Finally, data on interest rates for loans and deposits are from the monthly interest rate statistics ("Zinsstatistik"). Banks have to report these statistics to the Bundesbank upon random request by the Bundesbank. Hence for our banks we have a wide variety of data available including brokerage accounts, retail consumer loans, the loan rates they charged and the deposit rates that they offered. 


\section{Retail clientele and IPOs}

Table 1 provides some descriptive statistics of the 72 IPOs that we have. While the IPOs in our sample are underpriced on average by $25 \%$ there is a fair amount of variation in the level of underpricing. As table 2 documents 24 of these issues are highly underpriced with underpricing exceeding $25 \%, 21$ of these issues either have zero underpricing or are overpriced, and 27 of these issues are moderately underpriced between $0-25 \%$. Similar patterns obtain for the smaller sample of 44 IPOs for which we have with the lead bank clientele demand.

For our purpose we want to see whether there are differential patterns of demand and allocation if the retail clientele is with the lead bank vis-à-vis other retail clientele. We first examine the shares demanded by all retail investors. Table 2 shows the overall demand as well as demand by various retail clienteles. IPOs are split into three categories. Overpriced, i.e., the offer price is equal or greater than the first day trading price; moderately underpriced where the range of underpricing is in the range of $0-25 \%$; and highly underpriced where the level of underpricing is greater than $25 \%$. The percentage of shares demanded by retail investors varies considerably across the lead underwriter retail clientele versus non-lead underwriter clientele. There is an interesting pattern in the proportional demand of lead underwriter retail clientele versus non-lead underwriter retail clientele. The percentage of shares demanded by the lead banks' retail clientele increases from $10.73 \%$ for overpriced issues to $11.59 \%$ for moderately underpriced issues and $15.18 \%$ for highly underpriced issues. In contrast, the percentage of shares demanded by non-lead bank clientele trends downward from $13.17 \%$ for overpriced issues, $10.02 \%$ for moderately underpriced issues and $8.98 \%$ for highly underpriced issues. Thus, the percentage of shares demanded by lead underwriters retail clientele increases for underpriced issues while the percentage of demand of other retail actually decreases. In the former, there is an upward trending demand, and in the latter there is a downward trending demand with the difference between the two being statistically significant. 
Next we examine allocations to different groups of retail clientele. Table 3 examines the raw allocation percentage to lead retail clientele and non-lead retail clientele. Table 3 shows an interesting pattern, namely, lead retail customers are more likely to get a higher allocation of highly underpriced issues than non-lead retail. Thus, lead retail get $10.22 \%$ allocation of the overpriced issues, $14.59 \%$ of the moderately underpriced issues and $12.16 \%$ of highly underpriced issues. In comparison, all other retail get $13.07 \%$ of the overpriced issues, $10.73 \%$ of the moderately underpriced issues and only $8.30 \%$ of the highly underpriced issues. Hence ultimately, the lead bank retail clientele earner higher profits from the IPOs that they obtain as compared to the non-lead bank retail clientele.

The above results are interesting but only suggestive as we also need to control for other factors when examining demand and allocation of IPO shares. We collect data on some of the factors we think are ex-ante important. We next test for differences in demand and allocation to different sets of retail investors through a multivariate framework. The independent variables that we use are the following:

LNPROCEEDS: The size of the issue is likely to be important as larger IPOs may attract more attention and more subscribers. Conversely, it could be the case that it is harder to get the necessary subscription in larger IPOs and that more marketing effort is needed.

LN SYNDICATE SIZE: The syndicate size should affect the demand and perhaps the allocation of IPO shares for lead retail as opposed to other retail. The larger the syndicate size the smaller one would expect the lead retail customers' demand and allocation to be.

HI-TECH INDUSTRY: The kind of industry could be important as shown by Loughran and Ritter (2004) and Ljungqvist and Wilhelm (2003), and following their procedure we incorporate a dummy if the issue is in the high-tech industry.

TIMING: The 1999-2000 market was a hot market. This can influence investor demand and accordingly we introduce a timing dummy corresponding to this period. 
PRICE UPDATE: Finally, the final offer price as related to the mid-point of the filing range has been shown to be a significant determinant of underpricing in U.S. IPOs (see e.g., Hanley, 1993, and Aggarwal, Prabhala and Puri, 2002). Hence we also include this variable that captures the ratio of the offer price to the mid-point of the filing range.

Next we run regressions examining how demand and allocation to retail customers are affected by the level of underpricing, after controlling for the above factors. We have two separate dependent variables. The first is lead retail customers. The second is non-lead retail. We run regressions for these two samples.

Table 4, column 1, has the dependent variable as the percentage of shares demanded by non-lead retail customers. The independent variables are lnproceeds, ln syndicate size, high tech dummy and percentage underpricing. The only independent variable that is significant is underpricing. The higher the underpricing the less the percentage of shares demanded by other retail investors, even after controlling for other factors. We add as independent variables our timing dummy in column 2, and then price update in column 3. In each case the additional variables are insignificant, and underpricing continues to be statistically significant.

Table 4, columns 4-6 shows similar regressions when the dependent variable is lead bank retail clientele. The table shows that the percentage of shares demanded by lead retail customers is significantly affected by two factors. The first is syndicate size. As syndicate size goes up the percentage of shares demanded by lead retail customers goes down. This is quite intuitive since with a larger syndicate there are more retail customers in aggregate applying for shares. For our purpose the important variable is underpricing which is positive and significant. The higher the issue is underpriced, the higher the percentage shares demanded by lead retail customers. All put together, Table 5 paints a reasonably convincing picture that lead retail customers' demand for shares is positively related to underpricing, and this seems to be at the expense of other retail investors.

Why do we see these differential patterns in demand? Lead bank retail clientele appear to have better information about underpriced issues than non-lead bank retail clientele. There are two 
possible explanations. One possible explanation is that the lead underwriter conveys information about good issues to its retail customers leading to a proportionately higher subscription of underpriced issues by its retail customers. A second possibility is the existence of when-issued or grey markets in the European IPO markets as a potential source of information for investors. In these forward markets, which are provided by several independent brokers, contracts on the issuing shares are traded. The prices for these contracts are continuously updated and are made publicly available. Cornelli, Goldreich, and Ljungqvist (2005) and Dorn (2004) provide a detailed description of these markets and document a positive relation between the price in the when-issued market and the price in the aftermarket. Our results are also consistent with the notion that retail investors follow prices in the when issued market and flock to the lead underwriter for placing their orders of underpriced issues, perhaps hoping for better access and/or allocation of new issues.

Table 5 examines allocations for these two groups of retail investors. In table 5 , column 1 , the dependent variable is the percentage shares allocated to non-lead retail clientele. Notice that in column 1, the only significant variable is underpricing of the IPO which is negatively related to the allocation to non-lead retail clientele. When we add other factors such as timing and the price revision and demand, underpricing remains significant. In columns (4)-(6) we examine the factors affecting lead retail allocation. In column (5) the only variable which is significant is $\ln$ syndicate size. When we add the timing variable, price update and demand, demand turns out to be very important. Statistically and economically the most significant factor is the percentage of the total demand. This is entirely intuitive as allocation should indeed be a function of the demand. In all, the results indicate that underpricing of the IPO is weakly significant in affecting allocation to non-lead retail and insignificant in affecting allocation to lead retail.

The overall picture is one in which lead underwriter retail clientele end up demanding more of the underpriced issues. Contrary to the beliefs of some, banks are not using their clout with retail customers to push subscriptions to "lemons" or overpriced issues. Rather the evidence is consistent with the notion that banks encourage their customers to subscribe to "hot" issues rather than "lemons," and treat them fairly in allocations. Ultimately, this allows lead bank retail clientele to obtain higher profits than other banks' retail clientele. 
Why should banks engage in such behavior? One plausible explanation is that of "cross-selling." By treating their retail customers fairly in "hot" IPOs, encouraging their demand for such IPOs, and not dumping them with more of the overpriced "lemons," banks ensure that more and more customers will open brokerage accounts with them in order to apply for allocation of these IPOs and perhaps also use other services of the bank. We use the aggregrate level bank data we obtain from the Bundesbank to explore this more fully.

\section{Cross-Selling to Retail Clientele}

The second data set we collect and now use consists of various confidential bank-specific statistics, which are provided by Deutsche Bundesbank, augmented with publicly available information from other sources. This data set covers the time period between 1992 and 2003. To begin our analysis, it is useful to compare and contrast private banks who underwrite IPOs to private banks who do not underwrite. We have data on 15 banks of which 4 are the traditional big players, 5 are the newcomers to underwriting, and 6 are non-underwriters.

\subsection{Growth of brokerage accounts}

Table 6 shows the difference in growth rates across these three groups of private banks. The main difference is found in the period 1997-2000, where the growth in brokerage accounts with big players is $11.4 \%$, with the new underwriters it is $9.6 \%$ while for non-underwriters it is only 2.4\%. Before 1997 and after 2000 the growth rates across the different bank groups are very similar and not statistically different from each other. The same holds for the growth rates in each of the given bank groups before 1997 and after 2000. The significance tests in table 6 confirm that the main differences arise from the underwriting banks, which are the big players and the new underwriters, in the period between 1997 and 2000.

Clearly the growth in brokerage accounts can be affected by other factors. We next build a set of factors that, a priori, might affect brokerage accounts growth. The first factor would be 
increased stock market participation in general, that could lead to an increase in brokerage accounts. In order to control for this we create a variable to capture growth of shareholders. The 1999-2000 period was a period of heightened stock market activity which could also lead to a growth of brokerage accounts so we create a dummy variable to capture this time period. The second factor that could influence the growth of brokerage accounts is the general growth of the bank. If it is the case that the bank is growing in general then this could account for the growth in brokerage accounts too. To control for this we create a variable which is growth in bank assets. Additionally, we use the one-period lag of IPOs as an instrument and reestimate our results. The third factor that could be responsible for the growth in brokerage accounts could be aggressive pricing by the bank. We obtain estimates of the brokerage fees as well as the lending rates and deposit rates of the bank to take this possibility into account. The independent variables that we use are given below.

LN Assets: The size of the bank is likely to be important though it is not obvious in which direction this factor will play. A larger bank may find it more difficult to achieve the same growth rates in retail business as a smaller bank, given the larger starting base. Conversely, a larger bank may use its economies of scale by being able to sell a broader range of products to retail customers.

Growth in assets: The growth in a bank's number of brokerage accounts and the amount of its loans to retail customers might reflect its general growth of business activities. Therefore, it is important to control for a bank's growth in assets. We define growth in assets is the percentage change in bank assets between $\mathrm{t}-1$ and $\mathrm{t}$.

Deposit rate: A bank might offer high interest rates on deposits relative to its competitors to attract customer deposits and cross-sell other retail products. We define deposit rate as the difference between the rate that a bank offers their customers for a 1-month deposit of less than DM 100,000/EUR 50,000 and the average rate across all banks for these deposits.

Loan rate: The growth in retail loans depends on the interest rate that a bank charges in comparison to the interest rates charged by its competitors. The lower the loan rate, the easier it 
should be for a bank to sell loans to retail customers. Also, a low loan rate might be used as a cross-selling mechanism to attract other retail business, as for example brokerage accounts. We define loan rate as the difference between the rate that a bank charges its retail customers for a loan with a value of less than DM 200,000/EUR 100,000 and the average rate across all banks for these loans.

Brokerage fees: The growth in the number of brokerage accounts per bank is expected to decrease with the brokerage fees that a bank charges its customers for opening and maintaining a brokerage account. Lower brokerage fees might also be used to cross-sell other retail products. Brokerage fees are from the "FINANZtest" publication and represent the yearly fees to be paid for a brokerage account with a volume of EUR 50,000 (as of March 2003).

Growth in shareholder base: The number of brokerage accounts by retail customers in a bank should be positively correlated to the number of shareholders in the population. The more investors enter the stock market, the more brokerage accounts need to be opened. The number of shareholders in Germany is calculated on a yearly basis by the Deutsches Aktieninstitut (DAI) and the growth rates per year are included as a control variable.

Timing: The 1999-2000 market was a hot market. This can influence a bank's behavior in attracting retail business and deciding on the creditworthiness of retail customers. Accordingly we introduce a timing dummy corresponding to this period.

Table 7 reports the results of a multivariate regression in which the dependent variable is the growth in the number of brokerage accounts and the independent variables are the size of the bank, its lending and deposit rates relative to the market rate and its competitors, the number of IPOs underwritten by the bank in question. Consistent with our intuition, the number of IPOs is significantly related to the percentage growth in retail brokerage accounts. Next, we add as control variables, the growth in shareholder base and a timing dummy which is one for the years 1999 and 2000. These results are reported in column 2 and are very similar to our earlier results. In all these specifications we estimate the regression as a pooled OLS where we adjust the standard errors for heteroskedasticity and clustering. Next, we replace the number of IPOs 
underwritten by the bank with the number of underpriced IPOs. The results are reported in column (3) of Table 7 and shows number of underpriced IPOs to be positive and significantly related to growth in brokerage accounts.

There is still the possibility that the number of IPOs underwritten by the bank is not entirely exogenous. If the number of IPOs underwritten is correlated with the error term then we have a potential problem in our estimation. To correct for this we would then need to look for a suitable instrument. One possible instrument is to use the one period lagged number of IPOs as an instrument. Bound, Jaeger and Baker (1995) caution that any instrument used needs to be sufficiently correlated to the endogenous variable and recommend a test to check if the instruments are weak. The test they propose calculates the $\mathrm{R}^{2}$ of the first-stage regression with the included instruments "partialled-out" (equivalently described as the F-test of the joint significance of the excluded instruments in the first-stage regression). As a rule of thumb, instruments are weak if the F-statistic is below 10. For the one period lagged number of IPOs, the F statistic amounts to 16.44 . Hence this would appear to be a reasonable instrument to use.

We reestimate our specification with the one period lagged number of IPOs underwritten by the bank as an instrument. These are reported in Table 7, columns 4 and 5. After instrumenting for the number of IPOs we obtain very similar results as found before. Put together, the evidence suggests that the higher volume of IPOs underwritten by the bank, the greater the growth in brokerage accounts after controlling for other factors.

\subsection{Profitability of brokerage accounts}

How attractive are these brokerage accounts for the bank? One way to gauge the attractiveness of having brokerage accounts opened with the bank is to try to get a handle on the amount of fees that these accounts generate. There are two sources of fee revenue in such accounts. The first arises from transaction fees on trading activities. Information from customer handouts of two of the major banks (Deutsche Bank and Dresdner Bank) suggests that transaction fees for trading 
are $1 \%$. Based on estimated trading volume from multiple sources the average amount of trading fees on a given account is in the range of $€ 300$ per year. $^{3}$

The second source of fees is the fixed fees on the account itself, absent any trading activity. Fees for brokerage accounts are billed on a yearly basis and are the higher of a minimum fixed fee and a percentage of the market value of the brokerage account. The yearly minimum fees for regular brokerage accounts range from $€ 20$ to $€ 100$, while the percentage of the market value averages $0.15 \%$ across banks. Table 6 suggests that the number of brokerage accounts do not decrease over time, even when the IPO period shut down. Thus, there is a growth of $11.4 \%$ in brokerage accounts for the big four players and a growth of $9.6 \%$ for the new bank underwriters in the period 1997-2000 but a trivial decline of less than half a percent for the big four players and $1.1 \%$ for the new underwriters in the period 2001-2003. This suggests that even if the motivation for opening brokerage accounts is for IPO subscription once opened the brokerage accounts have a life of their own and tend to stay open well after the IPO activity is over, generating fixed fees even if there is no trading activity. ${ }^{4}$

The four big players in the previous analyses saw an average increase of 450,000 brokerage accounts between 1993 and 2003. This represents a substantial increase, as these banks had on average less than 1 million brokerage accounts in 1993. As a back-of-the-envelope estimate, the increase in the number of brokerage accounts therefore generated on average additional revenues of almost $€ 36.5$ million for each of these banks, just from the pure existence of the brokerage accounts (computation assumes $€ 81$ per year, see footnote 3 ). Note that this is a conservative figure, as it does not consider the revenues from trading in these accounts and any potential for cross-selling of other retail products.

\footnotetext{
${ }^{3}$ A major German bank provided us with figures on their regular, non-online retail customers' trading behavior in 2003. In an average brokerage account, transactions amount to about EUR 35,000. These numbers are also consistent with that of Comdirect, one of the leading providers for online brokerage accounts in Germany, which reported in its Annual Report 2001 that the average brokerage account has about 11 transactions in a year, and the average transaction volume amounts to $€ 3,000$, giving a total average transaction volume per account of $€ 30,000$. With transaction fees of $1 \%$ this accounts to more than $€ 300$ per year.

4 The publicly available Bundesbank statistic on brokerage accounts ("Statistische Sonderveröffentlichung 9, September 2004") reports for 2003 a total number of 3,455,000 retail brokerage accounts in large private banks. The total market value of holdings in these brokerage accounts amounts to $€ 186,882$ million. This implies an average value of $€ 54,090$ per brokerage account. At a percentage of $0.15 \%$ of market value this amounts to revenue of about $€ 81$ per year as an estimate of mimimum fees per account, assuming no trading activity.
} 


\subsection{Internal survey evidence from a sample bank}

There are a large number of consulting studies done on cross-selling for banks in general. However, the kind of detail that we would like to have on how opening a single account affects other retail services is often unavailable. We were able to access a proprietary study done for a major bank in Germany that examines the amount of cross-selling that occurs through brokerage accounts. The results of this study are interesting and worth reporting.

Table 8 reports the results on this study and shows that brokerage accounts often lead to a significant amount of other accounts being opened with the bank. While this data is from a single bank it is suggestive of the importance of a single account, here brokerage accounts, in cross-selling. Since brokerage accounts are often opened in conjunction with applications for IPOs, the results of this study underscores the importance of IPO activity to the retail business of the bank.

\subsection{Growth in retail consumer loans}

While brokerage accounts would appear to be the first thing one should examine in the context of IPOs, it is worth asking whether the banks' other retail services also experience a growth because of the banks' IPO underwriting activities. Cross-selling can also occur through other avenues and not just brokerage accounts. We do not have access to data on all services provided by the bank. However, we do have access to two useful ways to examine cross-selling. To test whether cross-selling occurs at a more general level we were able to obtain data on an aggregrate basis for multiple banks on retail consumer loans from the Deutsche Bundesbank.

We test if the growth in retail consumer loans is related to the IPO activity of the bank. Once again, we want to control for other factors that might affect the growth of consumer loans so we control for the competitive rates of the banks through its lending rates and deposit rates, and the growth of the banks. Table 9 shows that after controlling for the banks' asset base, the loan rate and deposit rates they offer, the number of IPOs is significantly correlated with the growth in 
consumer loans. In columns (2) and (3) we additionally add controls for the growth in shareholder base, as well as a timing dummy for the hot period of 1999 and 2000. The number of IPOs underwritten by the bank continues to be highly significantly associated with the growth of consumer loans. In column (4) we look at not just the number of IPOs the bank underwrote but instead ask if the number of underpriced IPOs underwritten by the bank is significantly correlated to the growth of consumer loans. Replacing the number of IPOs with the number of underpriced IPOs, we find the coefficient on underpriced IPOs is bigger and continues to be very significant. We run a number of robustness checks. First, the IPOs tend to cluster in time, so we adjust the standard errors for time clustering as well as for heteroskedasticity. Second, we reestimate the regression using the one period lagged IPO underwriting volume as an instrument along the spirit of table 7. Again the results are very similar with the number of IPOs being positive and significantly related to the growth in retail consumer loans. These results combined with the brokerage results are consistent with IPO activity enabling the bank to obtain significant cross-selling for different products of the bank.

\subsection{Corporate loans and IPO activity}

Above we find that the amount of IPO underwriting by a commercial bank is significantly related to its growth in brokerage accounts as well as growth of retail consumer loans. We now conduct a slightly different test. If it is the case that the increase in different services comes from the general growth of the bank, then we should see this on all dimensions. As a control group we examine the growth in corporate loans. If it is indeed the case that increased IPO underwriting is a way to increase the cross-selling activities of retail services then it is less likely to show up in corporate loans. The largest underwriting bank in this period, DG-Bank, underwrote 44 IPOs. Hence cross-selling with corporate clients is likely to be on a much smaller magnitude (maximum of 44 not excluding the fact that the bank is likely to already have a relationship with many of these corporate clients) than for retail accounts (where there are thousands of retail customers). The growth in the number of new brokerage accounts is likely coming from new clientele. 
Table 10 is estimated using the growth in corporate loans as the dependent variable. Controlling for factors such as the size of the bank, lending rates, deposit rates, shareholder growth and timing, we find that the number of IPOs is not significantly related to the growth of corporate loans. Again we reestimate using an instrumental variable approach similar to Table 7 . The results are very similar. In all, the IPO underwriting activity of the bank is highly correlated with growth in retail brokerage accounts and retail consumer loans and is not related to the growth in corporate loans.

\section{Conclusion}

The issue of IPO allocations to customers has been one that has received a lot of attention in the IPO literature both in theory and empirical work. The theoretical work has typically made a distinction between informed and uninformed investors (e.g., Rock (1986), Benveniste and Spindt (1989)). The empirical work, using theory as a base, has looked at the split between institutions and retail investors on the premise that institutional investors are informed and retail investors are not (see e.g., Hanley and Wilhelm (1995), Aggrawal, Prabhala, Puri (2002)). However, to the best of our knowledge, there has been no empirical work that examines the distinction between different kinds of retail clientele. Our paper fills the gap. We examine both differences in demand and allocation of IPOs to lead bank retail and non-lead bank retail customers using a unique proprietary database culled from the leading bank underwriters in Germany, and supplemented with aggregrate bank level data from the Deutsche Bundesbank.

These results are interesting on a number of dimensions. First, it suggests that underwriters care about their retail customers and work to treat them fairly, rather than pushing them to subscribe to lemons. Part of the reason for underwriters to treat their retail clientele fairly is because of the cross-selling that occurs from the IPO activity. We document that underwriting IPOs, particularly underpriced IPOs is significantly related to the number of brokerage accounts with the bank. Interestingly the brokerage accounts are not closed when there is a downturn in IPO activity suggesting that there is a lot of stickiness to such accounts and they continue to generate both fixed and trading fees well beyond the IPO window. In addition we also document that the 
growth in consumer loans is significantly positively related to the IPO underwriting of the bank, in particular the underwriting of underpriced IPOs. This result is also interesting from the perspective of the IPO literature where the focus has typically been on institutional clientele and how incentives to underprice can derive from institutional clientele. Our paper suggests that retail clientele can also be important from the bank's perspective and this too, can lead to incentives to underprice to attract retail customers who will also boost the banks' other related business. This is an interesting issue to think about on the theoretical as well as empirical dimension. A further interesting avenue for future research would be to examine the differences in the incentives and behavior of commercial cum investment banks vis-à-vis pure investment banks. This is particularly relevant as in many countries, such as the US, both commercial and investment banks do securities underwriting side by side. 


\section{References}

Aggarwal, Reena, Nagpurnanand Prabhala, and Manju Puri, 2002, Institutional Allocation in Initial Public Offerings: Empirical Evidence, Journal of Finance 57, 1421-1442.

Benveniste, Lawrence M., and Paul A. Spindt, 1989, How Investment Bankers Determine the Offer Price and Allocation of New Issues, Journal of Financial Economics 24, 213-232.

Bharath, Sreedhar, Sandeep Dahiya, Anthony Saunders and Anand Srinivasan, 2005, So What Do I Get? The Bank’s View of Lending, Journal of Financial Economics, forthcoming.

Bound, John, David A. Jaeger, Regina M. Baker, 1995, Problems with Instrumental Variables Estimation When the Correlation Between the Instruments and the Endogenous Explanatory Variable is Weak, Journal of the American Statistical Association, 90, 443-450.

Cornelli, Francesca, and David Goldreich, 2001, Bookbuilding and Strategic Allocation, Journal of Finance 56, 2337-2369.

Cornelli, Francesca, and David Goldreich, 2003, Bookbuilding: How Informative is the Order Book?, Journal of Finance 58, 1415-1444.

Cornelli, Francesca, David Goldreich, and Alexander Ljungqvist, 2006, Investor Sentiment and Pre-IPO Markets, Journal of Finance forthcoming.

Dorn, Daniel, 2004, Does Sentiment Drive the Retail Demand for IPOs?, Working Paper.

Drucker, Steven, and Manju Puri, 2005, On the Benefits of Concurrent Lending and Underwriting, Journal of Finance 60, 2763-2799.

Fulghieri, Paolo, and Matthew Spiegel, 1993, A Theory of the Distribution of Underpriced Initial Public Offers by Investment Banks, Journal of Economics \& Management Strategy 2, 509-530. 
Hanley, Kathleen Weiss, 1993, The underpricing of initial public offerings and the partial adjustment phenomenon, Journal of Financial Economics 34, 231-250

Hanley, Kathleen Weiss, and William J. Wilhelm, Jr., 1995, Evidence on the strategic allocation of initial public offerings, Journal of Financial Economics 37, 239-257

James, Christopher, 1992, Relationship-specific assets and the pricing of underwriter services, Journal of Finance 47, 1865-1885.

Ljungqvist, Alexander P., and William J. Wilhelm, 2002, IPO Allocations: Discriminatory or Discretionary?, Journal of Financial Economics 65, 167-201.

M. Nimalendran, Jay Ritter, and Donghang Zhang, 2006, Do Today's Trades Affect Tomorrow's IPO Allocation? Journal of Financial Economics forthcoming.

Ritter, Jay R., and Ivo Welch, 2002, A Review of IPO Activity, Pricing, and Allocations, Journal of Finance 57, 1795-1828.

Reuter, Jonathan, 2006, Are IPO Allocations for Sale? Evidence from the Mutual Fund Industry, Journal of Finance, forthcoming.

Rock, Kevin, 1986, Why New Issues are Underpriced, Journal of Financial Economics 17, 187212. 


\section{Table 1}

\section{Descriptive Statistics}

The table shows the mean and median descriptive statistics for the 72 issuing companies. LN Proceeds denote the natural logarithm of the amount raised; Shares offered represent the number of shares sold in the IPO (in million); Subscription level is the ratio of the number of shares demanded and shares offered; Syndicate size is the number of banks in the underwriting syndicate; UPDATE is the percentage change between the midpoint of the offer range and the final offer price; Underpricing is calculated as the percentage change between the offer price and the market-closing price on the first day of trading. Subscription levels are provided by the sample underwriter. The other figures are from SDC and Factiva.

.

\begin{tabular}{lcc}
\hline \hline Variable & Mean & Median \\
\hline \hline LN Proceeds (in $€$ million) & 19.93 & 18.53 \\
Shares offered (in € million) & 29.38 & 4.08 \\
Subscription level & 21.43 & 11.35 \\
Syndicate size & 5.58 & 4 \\
UPDATE (in \%) & 2.23 & 5.33 \\
Underpricing (in \%) & 25.73 & 4.76 \\
\hline \hline
\end{tabular}




\section{Table 2}

\section{Demand shares of retail investors (in percent of sum of shares demanded)}

The table reports the lead underwriter's (Lead) retail clientele demand for IPOs and the demand from retail investors of banks that are not the lead underwriter (Non-Lead). Demand (in percent) is calculated as the ratio of the number of shares demanded by these retail investors and the number of shares demanded by all investors. The first column reports the figures for all IPOs, the second to fourth column report the figures for different levels of underpricing (UP). The figures for the number of issues are denoted in italics. The last column reports the z-statistic for the comparison of means in the lowest and the highest return group. The last row reports the z-statistic for the comparison of means between Lead and Non-Lead. *, **,*** represent significance levels of 10,5 , and 1 percent, respectively.

\begin{tabular}{lccccc}
\hline \hline & All & $\mathrm{UP} \leq 0 \%$ & $0 \%<\mathrm{UP} \leq 25 \%$ & $25 \%<\mathrm{UP}$ & All \\
\hline Lead & 44 & 13 & 15 & 16 & \\
& 12.64 & 10.73 & 11.59 & 15.18 & $1.85^{*}$ \\
Non-Lead & 72 & 21 & 27 & 24 & $1.88^{*}$ \\
& 10.59 & 13.17 & 10.02 & 8.98 & $2.38^{* *}$ \\
z-stats & 1.23 & 1.03 & 0.18 & \\
\hline \hline
\end{tabular}


Table 3

\section{Allocation shares of retail investors (in percent of sum of shares sold)}

The table reports the allocation shares for retail investors of the lead underwriter (Lead) and for retail investors of banks that are not the lead underwriter (Non-Lead). Allocation shares (in percent) are calculated as the ratio of the number of shares allocated to these retail investors and the number of shares allocated to all investors. The first column reports the figures for all IPOs, the second to fourth column report the figures for different levels of underpricing (UP). The figures for the number of issues are denoted in italics. The last column reports the z-statistic for the comparison of means in the lowest and the highest return group. The last row reports the $\mathrm{z}$-statistic for the comparison of means between Lead and Non-Lead. *,**,*** represent significance levels of 10,5 , and 1 percent, respectively.

\begin{tabular}{lccccc}
\hline \hline & All & $\mathrm{UP} \leq 0 \%$ & $0 \%<\mathrm{UP} \leq 25 \%$ & $25 \%<\mathrm{UP}$ & All \\
\hline \hline Lead & 44 & 13 & 15 & 16 & \\
& 12.41 & 10.22 & 14.59 & 12.16 & 0.54 \\
Non-Lead & 72 & 21 & 27 & 24 & \\
& 10.60 & 13.07 & 10.73 & 8.30 & $1.92^{*}$ \\
z-stats & 1.18 & 0.62 & 0.88 & $2.54 * *$ & \\
\hline \hline
\end{tabular}




\section{Table 4}

\section{Demand OLS Regression for IPOs}

The two dependent variables are the demand shares for non-lead retail and lead retail investors, as defined in Table 3. LNPROCEEDS and LN Syndicate Size are the logs of proceeds and syndicate size, respectively. High-tech stocks are those with SIC codes 3571, 3572, 3575, 3577, 3578 (computer hardware), 3661, 3663, 3669 (communications equipment), 3671, 3672, 3674, 3675, 3677, 3678, 3679 (electronics), 3812 (navigation equipment), 3823, 3825, 3826, 3827, 3829 (measuring and controlling devices), 3841, 3845 (medical instruments), 4812, 4813 (telephone equipment), 4899 (communications services), and 7371, 7372, 7373, 7374, 7375, 7378, and 7379 (software), see Loughran and Ritter (2004). Underpricing and Price Update are categorial variables with levels 1 to 3.

\begin{tabular}{|c|c|c|c|c|c|c|}
\hline & $\begin{array}{c}\text { Non-Lead Retail } \\
\text { (1) } \\
\end{array}$ & $\begin{array}{c}\text { Non-Lead Retail } \\
\text { (2) } \\
\end{array}$ & $\begin{array}{c}\text { Non-Lead Retail } \\
\text { (3) } \\
\end{array}$ & $\begin{array}{c}\text { Lead Retail } \\
\text { (4) } \\
\end{array}$ & $\begin{array}{c}\text { Lead Retail } \\
\text { (5) } \\
\end{array}$ & $\begin{array}{c}\text { Lead Retail } \\
(6) \\
\end{array}$ \\
\hline Constant & $\begin{array}{c}0.414 \\
(2.40)^{* *}\end{array}$ & $\begin{array}{c}0.429 \\
(2.27)^{* *}\end{array}$ & $\begin{array}{c}0.443 \\
(2.13)^{* *}\end{array}$ & $\begin{array}{l}0.200 \\
(1.16)\end{array}$ & $\begin{array}{l}0.258 \\
(1.53)\end{array}$ & $\begin{array}{l}0.244 \\
(1.32)\end{array}$ \\
\hline LNPROCEEDS & $\begin{array}{r}-0.011 \\
(1.27)\end{array}$ & $\begin{array}{r}-0.013 \\
(1.40)\end{array}$ & $\begin{array}{r}-0.013 \\
(1.36)\end{array}$ & $\begin{array}{r}-0.001 \\
(0.12)\end{array}$ & $\begin{array}{c}-0.004 \\
(0.41)\end{array}$ & $\begin{array}{r}-0.003 \\
(0.25)\end{array}$ \\
\hline LN Syndicate Size & $\begin{array}{l}-0.022 \\
(1.10)\end{array}$ & $\begin{array}{l}-0.022 \\
(1.29)\end{array}$ & $\begin{array}{l}-0.022 \\
(1.22)\end{array}$ & $\begin{array}{c}-0.071 \\
(2.90)^{* * *}\end{array}$ & $\begin{array}{c}-0.071 \\
(2.83)^{* * *}\end{array}$ & $\begin{array}{c}-0.065 \\
(2.42)^{* * *}\end{array}$ \\
\hline $\begin{array}{l}=1 \text { if high-tech } \\
\text { industry }\end{array}$ & $\begin{array}{l}0.004 \\
(0.14)\end{array}$ & $\begin{array}{l}-0.007 \\
(0.23)\end{array}$ & $\begin{array}{l}-0.008 \\
(0.27)\end{array}$ & $\begin{array}{r}-0.040 \\
(1.53)\end{array}$ & $\begin{array}{r}-0.041 \\
(1.51)\end{array}$ & $\begin{array}{l}-0.041 \\
(1.44)\end{array}$ \\
\hline Underpricing & $\begin{array}{l}-0.031 \\
(1.81)^{*}\end{array}$ & $\begin{array}{l}-0.031 \\
(1.78)^{*}\end{array}$ & $\begin{array}{l}-0.031 \\
(1.74)^{*}\end{array}$ & $\begin{array}{c}0.030 \\
(1.97)^{*}\end{array}$ & $\begin{array}{c}0.030 \\
(1.95)^{*}\end{array}$ & $\begin{array}{c}0.033 \\
(2.13)^{* *}\end{array}$ \\
\hline $\begin{array}{l}=1 \text { if issue in } \\
1999 / 2000 \\
\text { Price Update }\end{array}$ & & $\begin{array}{c}0.031 \\
(1.19)\end{array}$ & $\begin{array}{c}0.032 \\
(1.23) \\
-0.004 \\
(0.24)\end{array}$ & & $\begin{array}{l}-0.011 \\
(0.44)\end{array}$ & $\begin{array}{c}-0.0152 \\
(0.59) \\
-0.013 \\
(0.76)\end{array}$ \\
\hline $\begin{array}{l}\text { Number of } \\
\text { Observations }\end{array}$ & 72 & 72 & 72 & 44 & 44 & 44 \\
\hline $\mathrm{R}^{2}$ & 0.09 & 0.12 & 0.13 & 0.30 & 0.32 & 0.32 \\
\hline
\end{tabular}


Table 5

Allocation OLS Regression for IPOs

The two dependent variables are the allocation shares for non-lead retail and lead retail investors. Demand (in \%) and Demand Lead/Non-Lead Retail are the dependent variables from Table 5. All the other variables are the same as in Table 5.

\begin{tabular}{|c|c|c|c|c|c|c|}
\hline & $\begin{array}{c}\text { Non-Lead Retail } \\
\text { (1) }\end{array}$ & $\begin{array}{c}\text { Non-Lead Retail } \\
\text { (2) }\end{array}$ & $\begin{array}{c}\text { Non-Lead Retail } \\
\text { (3) }\end{array}$ & $\begin{array}{c}\text { Lead Retail } \\
\text { (4) }\end{array}$ & $\begin{array}{c}\text { Lead Retail } \\
\text { (5) }\end{array}$ & $\begin{array}{c}\text { Lead Retail } \\
\text { (6) }\end{array}$ \\
\hline Constant & $\begin{array}{l}0.210 \\
(1.30)\end{array}$ & $\begin{array}{l}0.226 \\
(1.35)\end{array}$ & $\begin{array}{l}0.004 \\
(0.98)\end{array}$ & $\begin{array}{l}0.218 \\
(1.14)\end{array}$ & $\begin{array}{c}0.401 \\
(1.84)^{*}\end{array}$ & $\begin{array}{l}0.015 \\
(0.10)\end{array}$ \\
\hline LNPROCEEDS & $\begin{array}{l}-0.002 \\
(0.28)\end{array}$ & $\begin{array}{l}-0.004 \\
(0.46)\end{array}$ & $\begin{array}{l}0.004 \\
(0.55)\end{array}$ & $\begin{array}{r}-0.001 \\
(0.03)\end{array}$ & $\begin{array}{l}-0.009 \\
(0.74)\end{array}$ & $\begin{array}{l}0.003 \\
(0.43)\end{array}$ \\
\hline LN Syndicate Size & $\begin{array}{l}-0.004 \\
(0.21)\end{array}$ & $\begin{array}{l}-0.007 \\
(0.36)\end{array}$ & $\begin{array}{l}-0.014 \\
(0.58)\end{array}$ & $\begin{array}{c}-0.078 \\
(2.84)^{* * *}\end{array}$ & $\begin{array}{c}-0.074 \\
(2.25)^{* *}\end{array}$ & $\begin{array}{l}-0.030 \\
(1.36)\end{array}$ \\
\hline $\begin{array}{l}=1 \text { if high-tech } \\
\text { industry }\end{array}$ & $\begin{array}{l}-0.015 \\
(0.54)\end{array}$ & $\begin{array}{c}-0.0267 \\
(0.97)\end{array}$ & $\begin{array}{l}-0.014 \\
(0.58)\end{array}$ & $\begin{array}{r}-0.039 \\
(1.32)\end{array}$ & $\begin{array}{r}-0.043 \\
(1.26)\end{array}$ & $\begin{array}{l}0.006 \\
(0.25)\end{array}$ \\
\hline Underpricing & $\begin{array}{l}-0.025 \\
(1.76)^{*}\end{array}$ & $\begin{array}{l}-0.029 \\
(1.81)^{*}\end{array}$ & $\begin{array}{l}-0.035 \\
(1.68)^{*}\end{array}$ & $\begin{array}{l}0.014 \\
(0.86)\end{array}$ & $\begin{array}{l}0.016 \\
(0.85)\end{array}$ & $\begin{array}{l}-0.007 \\
(0.54)\end{array}$ \\
\hline $\begin{array}{l}=1 \text { if issue in } \\
1999 / 2000\end{array}$ & & $\begin{array}{c}0.052 \\
(2.11)^{*}\end{array}$ & $\begin{array}{l}0.031 \\
(1.38)\end{array}$ & & $\begin{array}{l}-0.031 \\
(1.01)\end{array}$ & $\begin{array}{l}-0.036 \\
(1.82)^{*}\end{array}$ \\
\hline Price Update & & $\begin{array}{r}-0.001 \\
(0.01)\end{array}$ & $\begin{array}{l}0.007 \\
(0.49)\end{array}$ & & $\begin{array}{l}-0.005 \\
(0.23)\end{array}$ & $\begin{array}{r}0.010 \\
(0.80)\end{array}$ \\
\hline Demand (in \%) & & & $\begin{array}{c}0.516 \\
(4.96)^{* * *}\end{array}$ & & & $\begin{array}{c}0.783 \\
(6.16)^{* * *}\end{array}$ \\
\hline $\begin{array}{l}\text { Number of } \\
\text { Observations }\end{array}$ & 72 & 72 & 72 & 44 & 44 & 44 \\
\hline $\mathrm{R}^{2}$ & 0.10 & 0.11 & 0.50 & 0.25 & 0.28 & 0.67 \\
\hline
\end{tabular}


Table 6

Growth rate in number of retail brokerage accounts by IPO Lead underwriters

The growth rate is the percentage difference in the number of brokerage accounts between the end of the previous and the end of the reported year. These figures are reported for each year between 1993 and 2003 and for three sub-periods. They are calculated from the yearly brokerage account statistic ("Depotstatistik") at Deutsche Bundesbank. Averages are reported for three groups of banks: 1) Banks that were traditionally lead underwriters in Germany ("Big players"); 2) Banks that only became lead underwriters in the boom period between 1997 and 2000 ("Newcomers"); 3) Banks that are no lead underwriters throughout the period ("Non-underwriters").

\begin{tabular}{cccc}
\hline \hline & Big players (4) & Newcomers (5) & Non-underwriters (6) \\
\hline \hline 1993 & $2.87 \%$ & $-7.86 \%$ & $-5.52 \%$ \\
1994 & $6.65 \%$ & $7.61 \%$ & $3.46 \%$ \\
1995 & $-3.21 \%$ & $-3.88 \%$ & $-4.14 \%$ \\
1996 & $1.93 \%$ & $1.97 \%$ & $-2.92 \%$ \\
1997 & $4.22 \%$ & $4.31 \%$ & $-2.32 \%$ \\
1998 & $5.57 \%$ & $11.34 \%$ & $1.79 \%$ \\
1999 & $19.85 \%$ & $10.15 \%$ & $1.14 \%$ \\
2000 & $16.65 \%$ & $12.64 \%$ & $9.41 \%$ \\
2001 & $-2.54 \%$ & $0.91 \%$ & $-0.11 \%$ \\
2002 & $0.93 \%$ & $-1.66 \%$ & $2.81 \%$ \\
2003 & $0.58 \%$ & $-2.64 \%$ & $-2.35 \%$ \\
Sub-periods & & & $-2.34 \%$ \\
$1993-1996$ & $2.00 \%$ & $-0.71 \%$ & $2.42 \%$ \\
$1997-2000$ & $11.37 \%$ & $9.56 \%$ & $0.09 \%$ \\
$2001-2003$ & $-0.36 \%$ & $-1.14 \%$ & \\
\hline \hline
\end{tabular}

\section{Significance tests}

The table reports the t-statistics for the comparison of means within and across the three bank groups: Big players (BP), Newcomers (NC), and Non-underwriters (NU). *, **,*** represent significance levels of 10, 5 , and 1 percent, respectively.

a) Comparison between time periods for a given bank group

\begin{tabular}{cccc}
\hline \hline & Big players (4) & Newcomers (5) & Non-underwriters (6) \\
\hline \hline $1993-1996 / 1997-2000$ & $2.22^{* *}$ & $4.44^{* * *}$ & $2.62^{* *}$ \\
$1997-2000 / 2001-2003$ & $2.51^{* *}$ & $4.73^{* * *}$ & 0.82 \\
$1993-1996 / 2001-2003$ & 0.70 & 0.07 & 0.04 \\
\hline \hline
\end{tabular}

b) Comparison between bank groups for a given time period

\begin{tabular}{cccc}
\hline \hline & Big players (4) & Newcomers (5) & Non-underwriters (6) \\
\hline \hline $1993-1996$ & 1.09 & 1.27 & 0.17 \\
$1997-2000$ & 0.97 & $4.01^{* * *}$ & $2.56^{* *}$ \\
$2001-2003$ & 0.29 & 0.23 & 0.35 \\
\hline \hline
\end{tabular}


Table 7

Multivariate analysis - Growth in number of brokerage accounts

LNASSETS is the natural logarithm of bank assets. Growth in assets is the percentage change in assets between t-1 and t. Loan rate is the difference between the rate that a bank charges its retail customers for a loan with a value of less than DM 200,000/EUR 100,000 and the average rate across all banks for these loans. Deposit rate is the difference between the rate that a bank offers their customers for a 1-month deposit of less than DM 100,000/EUR 50,000 and the average rate across all banks for these deposits. Brokerage fees are from the "FINANZtest" publication and represent the yearly fees to be paid for a brokerage account with a volume of EUR 50,000 (as of March 2003). Number of (underpriced) IPOs is the number of (underpriced) IPOs for which a bank is the lead underwriter in a given year. Growth in shareholder base is the percentage change in the number of shareholders in Germany in a given year, as published by the DAI (Deutsches Aktieninstitut). The IV estimations in model (4) and model (5) use the number of IPOs in t-1 as an instrument for the number of IPOs in t. The standard errors in each model are adjusted for heteroskedasticity and time-clustering.

Growth in number of brokerage accounts (in \%)

OLS estimation

IV estimation

\begin{tabular}{|c|c|c|c|c|c|}
\hline & (1) & (2) & (3) & (4) & (5) \\
\hline \multirow[t]{2}{*}{ Constant } & 0.082 & 0.040 & 0.034 & 0.091 & 0.058 \\
\hline & $(0.87)$ & $(0.45)$ & $(0.38)$ & $(0.91)$ & $(0.59)$ \\
\hline \multirow[t]{2}{*}{ LNASSETS } & -0.004 & -0.002 & -0.001 & -0.005 & -0.003 \\
\hline & $(0.84)$ & $(0.35)$ & $(0.28)$ & $(0.91)$ & $(0.51)$ \\
\hline \multirow[t]{2}{*}{ Growth in assets } & 0.085 & 0.040 & 0.035 & 0.078 & 0.032 \\
\hline & $(1.22)$ & $(0.59)$ & $(0.50)$ & $(0.91)$ & $(0.47)$ \\
\hline \multirow[t]{2}{*}{ Loan rate } & -0.096 & -0.108 & -0.108 & -0.094 & -0.103 \\
\hline & $(2.23)^{* *}$ & $(3.09)^{* *}$ & $(3.03)^{* *}$ & $(1.96)^{*}$ & $(2.46)^{* *}$ \\
\hline \multirow[t]{2}{*}{ Deposit rate } & 0.480 & 0.419 & 0.431 & 0.482 & 0.430 \\
\hline & $(1.65)$ & $(1.22)$ & $(1.30)$ & $(1.67)$ & $(1.25)$ \\
\hline \multirow[t]{2}{*}{ Brokerage fees } & -0.035 & -0.036 & -0.030 & -0.037 & -0.039 \\
\hline & $(0.33)$ & $(0.36)$ & $(0.31)$ & $(0.33)$ & $(0.37)$ \\
\hline \multirow[t]{2}{*}{ Number of IPOs } & 0.017 & 0.008 & & 0.018 & 0.011 \\
\hline & $(9.75)^{* * *}$ & $(2.56)^{* *}$ & & $(3.51)^{* * *}$ & $(1.76)^{*}$ \\
\hline \multirow[t]{2}{*}{ Growth in shareholder base } & & 0.197 & 0.196 & & 0.183 \\
\hline & & $(4.65)^{* * *}$ & $(4.92)^{* * *}$ & & $(4.72)^{* * *}$ \\
\hline \multirow[t]{2}{*}{$=1$ if 1999 or 2000} & & 0.039 & 0.046 & & 0.031 \\
\hline & & $(3.46)^{* * *}$ & $(4.55)^{* * *}$ & & $(1.82)^{*}$ \\
\hline \multirow[t]{2}{*}{ Number of underpriced IPOs } & & & 0.009 & & \\
\hline & & & $(3.75)^{* * *}$ & & \\
\hline $\mathrm{N}$ & 122 & 122 & 122 & 122 & 122 \\
\hline $\mathrm{R}^{2}$ & 0.31 & 0.39 & 0.39 & 0.31 & 0.39 \\
\hline
\end{tabular}


Table 8

\section{Cross-selling impact of brokerage accounts}

The table reports the product combinations that retail customers of the sample bank choose when they open a brokerage account with the sample bank. These figures refer to new customers in one calendar year during the sample period and only comprise those product combinations that are sold when the customer relation is initiated, but they exclude any product combinations that are sold subsequently.

\begin{tabular}{|c|c|c|c|}
\hline Product combination & Number of new customers & Share & Number of products \\
\hline Brokerage Account only & 9.143 & $15.65 \%$ & 1.00 \\
\hline $\begin{array}{l}\text { Brokerage Account and } \\
\text { Savings Account }\end{array}$ & 18.034 & $30.87 \%$ & 2.00 \\
\hline $\begin{array}{l}\text { Brokerage Account and } \\
\text { Savings Plan }\end{array}$ & 6.730 & $11.52 \%$ & 2.00 \\
\hline $\begin{array}{l}\text { Brokerage Account and } \\
\text { Current Account }\end{array}$ & 6.479 & $11.09 \%$ & 2.00 \\
\hline $\begin{array}{l}\text { Brokerage Account, Savings } \\
\text { Account, and Savings Plan }\end{array}$ & 2.541 & $4.35 \%$ & 3.00 \\
\hline $\begin{array}{l}\text { Brokerage Account and Other } \\
\text { Products }\end{array}$ & 13.331 & $22.82 \%$ & $2.49^{*}$ \\
\hline Total & 58.420 & $100.00 \%$ & 2.04 \\
\hline
\end{tabular}

*Average of the combination of brokerage accounts and other products. 


\section{Table 9}

\section{Multivariate analysis - Growth in amount of retail consumer loans}

The dependent variable is the growth in consumer loans. This is the yearly percentage change in the amount of loans to retail customers with a maturity of up to five years. These figures are calculated from the bank loan statistic ("Kreditnehmerstatistik") at Deutsche Bundesbank. The other variables are the same as in Table 8. The IV estimations in model (4) and model (5) use the number of IPOs in t-1 as an instrument for the number of IPOs in t. The standard errors in each model are adjusted for heteroskedasticity and time-clustering.

\begin{tabular}{|c|c|c|c|c|c|}
\hline & \multicolumn{5}{|c|}{ Growth in amount of consumer loans (in \%) } \\
\hline & \multicolumn{3}{|c|}{ OLS estimation } & \multicolumn{2}{|c|}{ IV estimation } \\
\hline & (1) & (2) & (3) & (4) & $(5)$ \\
\hline Constant & $\begin{array}{c}4.141 \\
(2.35)^{* *}\end{array}$ & $\begin{array}{c}4.045 \\
(2.31)^{* *}\end{array}$ & $\begin{array}{c}3.995 \\
(2.11)^{* *}\end{array}$ & $\begin{array}{c}4.454 \\
(2.22)^{* *}\end{array}$ & $\begin{array}{c}4.764 \\
(2.32)^{* *}\end{array}$ \\
\hline LNASSETS & $\begin{array}{l}-0.197 \\
(2.20)^{* *}\end{array}$ & $\begin{array}{l}-0.188 \\
(2.11)^{* *}\end{array}$ & $\begin{array}{l}-0.186 \\
(1.89)^{*}\end{array}$ & $\begin{array}{l}-0.220 \\
(2.01)^{*}\end{array}$ & $\begin{array}{c}-0.232 \\
(2.15)^{* *}\end{array}$ \\
\hline Growth in assets & $\begin{array}{r}-1.675 \\
(0.66)\end{array}$ & $\begin{array}{l}-2.56 \\
(1.04)\end{array}$ & $\begin{array}{l}-2.732 \\
(1.12)\end{array}$ & $\begin{array}{c}-1.936 \\
(0.72)\end{array}$ & $\begin{array}{l}-2.865 \\
(1.03)\end{array}$ \\
\hline Loan rate & $\begin{array}{l}-0.146 \\
(0.24)\end{array}$ & $\begin{array}{l}-0.209 \\
(0.34)\end{array}$ & $\begin{array}{l}-0.246 \\
(0.41)\end{array}$ & $\begin{array}{l}-0.229 \\
(0.42)\end{array}$ & $\begin{array}{l}-0.419 \\
(0.73)\end{array}$ \\
\hline Deposit rate & $\begin{array}{l}2.673 \\
(0.83)\end{array}$ & $\begin{array}{l}2.388 \\
(0.76)\end{array}$ & $\begin{array}{l}2.782 \\
(0.74)\end{array}$ & $\begin{array}{l}2.772 \\
(0.85)\end{array}$ & $\begin{array}{l}2.837 \\
(0.80)\end{array}$ \\
\hline Brokerage fees & $\begin{array}{l}-0.023 \\
(1.53)\end{array}$ & $\begin{array}{l}-0.022 \\
(1.51)\end{array}$ & $\begin{array}{l}-0.208 \\
(1.36)\end{array}$ & $\begin{array}{l}-0.023 \\
(1.63)\end{array}$ & $\begin{array}{l}-0.023 \\
(1.57)\end{array}$ \\
\hline Number of IPOs & $\begin{array}{c}0.218 \\
(2.33)^{* *}\end{array}$ & $\begin{array}{c}0.211 \\
(2.33)^{* *}\end{array}$ & & $\begin{array}{c}0.263 \\
(2.31)^{* *}\end{array}$ & $\begin{array}{c}0.328 \\
(2.40)^{* *}\end{array}$ \\
\hline Growth in shareholder base & & $\begin{array}{c}3.604 \\
(2.59)^{* *}\end{array}$ & $\begin{array}{c}3.516 \\
(2.67)^{* *}\end{array}$ & & $\begin{array}{c}3.061 \\
(2.17)^{* *}\end{array}$ \\
\hline$=1$ if 1999 or 2000 & & $\begin{array}{c}-0.706 \\
(4.23)^{* * *}\end{array}$ & $\begin{array}{l}-0.573 \\
(2.97)^{* *}\end{array}$ & & $\begin{array}{c}-1.026 \\
(3.94)^{* * *}\end{array}$ \\
\hline Number of underpriced IPOs & & & $\begin{array}{c}0.250 \\
(1.76)^{*}\end{array}$ & & \\
\hline $\mathrm{N}$ & 122 & 122 & 122 & 122 & 122 \\
\hline$\overline{\mathrm{R}^{2}}$ & 0.18 & 0.22 & 0.22 & 0.18 & 0.19 \\
\hline
\end{tabular}




\section{Table 10}

\section{Multivariate analysis - Growth in amount of corporate loans}

The dependent variable is the growth in corporate loans. This is the yearly percentage change in the amount of loans to corporate borrowers with a maturity of up to five years. These figures are calculated from the bank loan statistic ("Kreditnehmerstatistik") at Deutsche Bundesbank. The other variables are the same as in Table 8. The IV estimations in model (4) and model (5) use the number of IPOs in t-1 as an instrument for the number of IPOs in t. The standard errors in each model are adjusted for heteroskedasticity and time-clustering.

\begin{tabular}{|c|c|c|c|c|c|}
\hline & \multicolumn{5}{|c|}{ Growth in amount of corporate loans (in \%) } \\
\hline & \multicolumn{3}{|c|}{ OLS estimation } & \multicolumn{2}{|c|}{ IV estimation } \\
\hline & (1) & (2) & (3) & (4) & (5) \\
\hline Constant & $\begin{array}{l}0.295 \\
(0.77)\end{array}$ & $\begin{array}{l}0.386 \\
(1.08)\end{array}$ & $\begin{array}{l}0.361 \\
(0.98)\end{array}$ & $\begin{array}{l}0.355 \\
(0.75)\end{array}$ & $\begin{array}{l}0.445 \\
(0.90)\end{array}$ \\
\hline LNASSETS & $\begin{array}{l}-0.016 \\
(0.60)\end{array}$ & $\begin{array}{r}-0.021 \\
(0.89)\end{array}$ & $\begin{array}{l}-0.020 \\
(0.80)\end{array}$ & $\begin{array}{l}-0.020 \\
(0.68)\end{array}$ & $\begin{array}{l}-0.025 \\
(0.82)\end{array}$ \\
\hline Growth in assets & $\begin{array}{c}0.659 \\
(1.86)^{*}\end{array}$ & $\begin{array}{c}0.799 \\
(2.58)^{* *}\end{array}$ & $\begin{array}{c}0.809 \\
(2.63)^{* *}\end{array}$ & $\begin{array}{l}0.609 \\
(1.22)\end{array}$ & $\begin{array}{c}0.774 \\
(2.30)^{* *}\end{array}$ \\
\hline Loan rate & $\begin{array}{l}-0.189 \\
(0.55)\end{array}$ & $\begin{array}{r}-0.167 \\
(0.48)\end{array}$ & $\begin{array}{r}-0.175 \\
(0.49)\end{array}$ & $\begin{array}{l}-0.173 \\
(0.57)\end{array}$ & $\begin{array}{r}-0.150 \\
(0.48)\end{array}$ \\
\hline Deposit rate & $\begin{array}{l}-0.910 \\
(0.20)\end{array}$ & $\begin{array}{l}-0.849 \\
(1.03)\end{array}$ & $\begin{array}{l}-0.864 \\
(1.06)\end{array}$ & $\begin{array}{l}-0.967 \\
(1.31)\end{array}$ & $\begin{array}{l}-0.811 \\
(1.00)\end{array}$ \\
\hline Brokerage fees & $\begin{array}{l}0.001 \\
(0.20)\end{array}$ & $\begin{array}{l}0.001 \\
(0.19)\end{array}$ & $\begin{array}{l}0.001 \\
(0.20)\end{array}$ & $\begin{array}{l}0.001 \\
(0.15)\end{array}$ & $\begin{array}{l}0.001 \\
(0.16)\end{array}$ \\
\hline Number of IPOs & $\begin{array}{l}-0.013 \\
(0.97)\end{array}$ & $\begin{array}{l}0.004 \\
(0.83)\end{array}$ & & $\begin{array}{l}-0.004 \\
(0.10)\end{array}$ & $\begin{array}{l}0.014 \\
(0.29)\end{array}$ \\
\hline Growth in shareholder base & & $\begin{array}{l}-0.598 \\
(0.83)\end{array}$ & $\begin{array}{l}-0.579 \\
(0.79)\end{array}$ & & $\begin{array}{l}-0.642 \\
(0.82)\end{array}$ \\
\hline$=1$ if 1999 or 2000 & & $\begin{array}{l}-0.039 \\
(0.29)\end{array}$ & $\begin{array}{c}-0.028 \\
(0.22)\end{array}$ & & $\begin{array}{l}-0.065 \\
(0.42)\end{array}$ \\
\hline Number of underpriced IPOs & & & $\begin{array}{l}0.001 \\
(0.01)\end{array}$ & & \\
\hline $\mathrm{N}$ & 122 & 122 & 122 & 122 & 122 \\
\hline $\mathrm{R}^{2}$ & 0.03 & 0.04 & 0.04 & 0.03 & 0.04 \\
\hline
\end{tabular}


